\title{
PROGRAM HARI BERBAGI KOMUNITAS BISA DI MTS. AL-MUWAFIQ
}

\author{
Teguh Nurhadi Suharsono ${ }^{1}$, Riffa Haviani Laluma ${ }^{2}$, Nurlatifah ${ }^{3}$ \\ 1, 2,3 S1-Teknik Informatika, Fakultas Teknik, Universitas Sangga Buana \\ ${ }^{1}$ korespondensi : teguh.nurhadi@usbypkp.ac.id
}

\begin{abstract}
ABSTRAK
Madrasah Al-Muwafiq, Cicalengka, Kabupaten Bandung, merupakan salah satu sekolah di daerah terpencil, yang membutuhkan dorongan untuk semangat belajar dalam menggapai cita-cita. Mengingat pentingnya masa remaja, sebagai masa pembentukan jadi diri seseorang, maka Hari Berbagi ditujukan bagi siswa-siswi MTS. proses belajar mengajar orang dewasa (POD) dan Psikoedukasi. Diharapkan dengan adanya program ini, para siswa-siswi menjadi termotivasi untuk mengerahkan potensi yang dimiliki untuk mencapai cita-citanya, serta mampu bersaing sesuai dengan tuntutan jaman.
\end{abstract}

Kata Kunci: Hari Berbagi, POD, Psikoedukasi.

\begin{abstract}
Madrasah Al-Muwafiq, Cicalengka, Bandung Regency, is one of the schools in a remote area, which needs encouragement for the enthusiasm of learning to achieve goals. Given the importance of adolescence, as a period of shaping one's self, the Day of Sharing is aimed at MTS students. Adult Teaching and Learning Process (POD) and Psychoeducation. It is hoped that with this program, students will be motivated to mobilize their potential to achieve their goals, and be able to compete in accordance with the demands of the times.
\end{abstract}

Keywords: Sharing Day, POD, Psychoeducation

\section{PENDAHULUAN}

Madrasah Al-Muwafiq, Cicalengka, Kabupaten Bandung, merupakan salah satu sekolah di daerah terpencil, yang membutuhkan dorongan untuk semangat belajar dalam menggapai citacita. Komunitas BISA dibentuk dengan tujuan untuk membangkitkan kembali semangat siswa-siswi dalam meraih apa yang menjadi cita-citanya. Diharapkan dengan adanya komunitas ini, siswa-siswi di sekolah mampu mengenal berbagai macam profesi, meningkat kepercayaan dirinya dan lebih siap dengan berbagai tantangan juga dapat mendongkrak semangat mereka dalam mencapai impian .

Demi terwujudnya harapan tersebut, maka Komunitas BISA membuat suatu program berbagi inspirasi yang disebut Hari Berbagi. Program Hari Berbagi ini merupakan suatu program sukarela dari para relawan tergabung, untuk berbagi cerita dan pengalaman mengenai hal-hal apa saja yang sudah dilakukan sehingga mereka mampu bersaing di dunia kerja sesuai dengan profesinya masing-masing.

Mengingat pentingnya masa remaja, sebagai masa pembentukan jadi diri seseorang, maka Hari Berbagi ditujukan bagi siswa-siswi MTS. Diharapkan dengan adanya program ini, para siswa-siswi menjadi termotivasi untuk mengerahkan potensi yang dimiliki untuk mencapai cita-citanya, serta mampu bersaing sesuai dengan tuntutan jaman. 


\section{METODE}

Pada kegiatan kali ini metode yang akan diterapkan yaitu proses belajar mengajar orang dewasa (POD) dimana seluruh proses belajar mengajar orang dewasa mengajak peran serta peserta turut aktif sebagai nara sumber [1]. Pola interaksi yang di bangun untuk saling memperkaya pemahaman masing-masing dengan menggunakan pendekatan pendidikan kritis, sehingga dalam pelatihan tersebut terbangun pola saling asah, asih dan asuh dalam proses belajarnya.

Sedang secara teknis metode penyampaian materi kegiatan ini dapat berupa ceramah/paparan singkat sebagai pengantar, penugasan, kerja kelompok, tanya-jawab dialogis, dan bisa juga berupa testimony serta simulasi.

Selain metode yang telah disebutkan di atas, diterapkan juga metode Psikoedukasi. Metode ini merupakan salah satu bentuk dari intervensi, baik untuk keluarga maupun perseorangan atau kelompok yang merupakan bagian dari terapi psikososial [2]. Tujuan dari program psikoedukasi adalah menambah pengetahuan tentang permasalahan yang sedang dihadapi oleh klien dan meningkatanfungsinya dalam lingkungannya [3]. Komunitas BISA memfokuskan pada materi "Self Control", yaitu sharing kemampuan untuk membimbing tingkah laku sendiri; kemampuan untuk menekan atau merintangi impuls-impuls atau tingkah laku impulsive [4].

\section{HASIL DAN PEMBAHASAN}

Program Hari Berbagi dilaksanakan selama 1 hari, pada tanggal 07 Desember 2019, mulai dari pukul 07.00 sampai dengan pukul 14.30, bertempat di MTS Al-Muwafiq, Cicalengka, Kabupaten Bandung.

Kegiatan tersebut diikuti oleh seluruh siswa MTS Al-Muwafiq, dengan rincian sebagai berikut:

Tabel 1 : Peserta Program Hari Berbagi

\begin{tabular}{|c|c|c|}
\hline Kelas & Jumlah Rombel & Jumlah Siswa \\
\hline Kelas VII & 3 & 123 \\
\hline Kelas VIII & 3 & 128 \\
\hline Kelas IX & 2 & 59 \\
\hline Total & $\mathbf{8}$ & $\mathbf{3 0 4}$ \\
\hline
\end{tabular}

Tujuan dari dilaksanakannya program Hari Berbagi ini adalah :

1. Siswa-siswi mendapatkan pengetahuan mengenai segala jenis profesi yang ada.

2. Siswa-siswi tergugah untuk memiliki dan berpegang teguh pada cita-cita yang dimiliki

3. Siswa-siswi mampu mengerahkan segala potensi yang dimiliki dalam meraih citacitanya.

4. Menumbuhkan motivasi dan rasa percaya diri, guna kesiapan untuk bersaing dengan 
yang lain.

Dalam mencapai tujuan serta output pelatihan, maka materi yang akan dibahas antara lain, sebagai berikut:

Tabel 2 : Materi Program Berbagi

\begin{tabular}{|c|c|}
\hline Tema & JPL \\
\hline My Inspiring Teacher & $1 \mathrm{JPL}$ \\
\hline Pendidik dengan dan dari hati & $1 \mathrm{JPL}$ \\
\hline Set the conviction to rise up the storms of life & $1 \mathrm{JPL}$ \\
\hline Kreatif Thinking dan Spslusi Alternatif & $1 \mathrm{JPL}$ \\
\hline Bisnis Dengan IT & $1 \mathrm{JPL}$ \\
\hline IT Sahabat Milenial & $1 \mathrm{JPL}$ \\
\hline A Journey of A Thousand Miles Begins with single step & $1 \mathrm{JPL}$ \\
\hline Menjadi sosok mulia karena karya & $1 \mathrm{JPL}$ \\
\hline Wirausaha - Ada apa dengan cita-cita? & $1 \mathrm{JPL}$ \\
\hline Dengan Menulis, kita membuka jendela dunia & $1 \mathrm{JPL}$ \\
\hline IT 4.0 & $1 \mathrm{JPL}$ \\
\hline Pentingnya pola hidup sehat bagi remaja & $1 \mathrm{JPL}$ \\
\hline Peluang perkembangan IT untuk milenial & $1 \mathrm{JPL}$ \\
\hline Perempuan milenial & $1 \mathrm{JPL}$ \\
\hline ORIGAMI & $1 \mathrm{JPL}$ \\
\hline MARKETER & $1 \mathrm{JPL}$ \\
\hline AO Bank & $1 \mathrm{JPL}$ \\
\hline Verse of the Universe & $1 \mathrm{JPL}$ \\
\hline Mental Tangguh & $1 \mathrm{JPL}$ \\
\hline Clinical Psychologist & $1 \mathrm{JPL}$ \\
\hline Pengenalan dunia IT & $1 \mathrm{JPL}$ \\
\hline
\end{tabular}

Materi-materi tersebut disampaikan oleh beberapa motivator. Motivator merupakan sebutan bagi para relawan tergabung, yang akan berbagi pengalaman, guna membangkitkan inspirasi bagi para peserta. Jumlah relawan untuk kegiatan kali ini ada 26 relawan, dengan 21 relawan sebagai motivator di kelas, dan 5 orang relawan sebagai dokumentator.

Kegiatan Pengabdian Kepada Masyarakat untuk meningkatkan rasa percaya diri anak- 
anak didik oleh komunitas mendapatkan sambutan yang luar biasa baik dari kepala sekolahnya, guru-gurunya bahkan dari murid MTs Al-Muwafiq. Namun bukan berarti tidak ada hambatan . berikut faktor pendukung dan factor hambatan yng dihadapi :

1. Faktor Pendukung

Yang mendukung terlaksananya pengabdian kepada masyarakat Adalah anak-anak yang semangat di kelas-kelas mendengarkan pemateri dari berbagai bidang ilmu, ada dari bidang psikologi, IT, bidan dan sebagainya, dan juga diadakan game yang mengasah dan mendidik ilmu.

2. Faktor Hambatan

Faktor penghambat dalam melaksanakan kegiatan ini :

a. waktu yang kurang lama, sehingga dianggap kurang

b. tidak adanya sinyal wifi sehingga mau presentasi video agak susah.

\section{PENUTUP}

Hasil yang diharapkan melalui kegiatan Hari Berbagi adalah sebagai berikut :
1. Tersedianya siswa-siswi yang percaya diri dan mampu mengerahkan potensi yang dimiliki untuk mencapai cita-citanya.

2. Tersedianya siswa-siswi yang mempunyai kesiapan untuk bersaing sesuai dengan tuntutan jaman.

3. Menstimulasi Softskill siswa untuk siap menghadapi tantangan kehidupan

4. Menstimulasi kepedulian siswa terhadap permasalahan di lingkungan sekitarnya.

Program Hari Berbagi ini diharapkan pula menjadi kegiatan yang dapat rutin dilaksanakan di MTS. Al-Muwafiq dengan materi-materi lainnya yang lebih bermanfaat lagi.

\section{DAFTAR PUSTAKA}

[1] http://siakpel.bppsdmk.kemkes.go.id: 8102/akreditasi_kurikulum/modul_2010 210432439034d69c49a02d61c68b6d43a 071927d.pdf

[2] Soep (2009). Pengaruh intervensi psikoedukasi dalam mengatasi depresi postpartum di rsu dr. pirngadi medan. Tesis: Universitas Sumatera Utara.

[3] Atmasari, Luthfi. (2019). Rancangan Intervensi pada Remaja Bersiko sebagai Upaya Meningkatkan Kesadaran Kesehatan Reproduksi. Happiness, 3(2), 77-86.

[4] Chaplin J.P 2004, Hal: 451.Kamus Lengkap Psikologi. Jakarta : Rajawali Press 